This is an Author's Accepted Manuscript of an article published in Continuum: Journal of

Media \& Cultural Studies, Volume 23, Issue 6, 2009 @ Taylor \& Francis, available online at:

http://www.tandfonline.com/ 10.1080/10304310903294739

\title{
Franchise nations: The future of the nation?
}

Susan Leong*

Faculty of Media, Culture \& Creative Arts, Curtin University of Technology, Perth, Australia

In this paper, I extend the notion of franchise nations, borrowed from Neal Stephenson's cyberpunk novel Snow Crash (1993), in order to employ it as a device for thinking about the future of the nation. I argue the concept to be particularly well suited for such contemplation because of its sound grounding in the historical intermesh of economic, political and cultural motivations intrinsic to the concept as well as lived experience of the nation. I illustrate this very briefly by casting (mainland) China as the master franchisor and the overseas Chinese as franchisees. Specifically, I discuss the media events concerning China that took place during 2008, such as the protests and counter-protests that occurred at various legs of the Olympic Torch Relay, the Sichuan earthquake of 12 May and the opening ceremony of the Beijing Olympics on 8 August, and reactions to these happenings from overseas Chinese located variously in Australia, Canada and the United States. I argue that employing the notion of franchise nations lays bare the commercial and political instrumentalism behind the promotion and courtship of diasporas by home nations but, crucially, also aids in the understanding of the reciprocal processes by which franchisees are fashioned out of these communities. Finally, I suggest that, aside from China, franchise nations may also be a useful approach for thinking about how nations like India and Singapore are expanded, exported and explained into the future.

\section{Dial 1-800-Nation}

The franchise and the virus work on the same principle: what thrives in one place will thrive in another. You just have to find a sufficiently virulent business plan, condense it into a threering binder - its DNA - xerox it, and embed it in the fertile lining of a well-traveled highway, preferably one with a left-turn lane. Then the growth will expand until it runs up against its property lines. (Stephenson 1993, 178)

In an age when national sovereignty and belonging are the cause of serious strife and vexation, it seems contrarily playful to address the nation's future development through the work of science fiction. Yet, as Blanchot $(2006,377)$ reminds us, the proper use of science fiction is to portray 'the most improbable present imaginable'. According to Suvin (1979, qtd in Kitchin and Kneale 2002, 4), science fiction usually achieves this through the broaching of a novum, a device that is equal parts novelty and innovation. I, therefore, intend here to borrow the novum of franchise nations from Stephenson's cyberpunk novel Snow Crash (1993) and deploy it to think about some of the contemporary developments of the nation. I argue franchise nations to be a pertinent approach because of the marked intensity in current patterns of migration and transnational populations and suggest, in particular, that it might serve as an entry point into thinking about the renewed focus on diaspora across the world.

\footnotetext{
*Email: susan.leong@exchange.curtin.edu.au
} 
Generally speaking, there are two types of franchises: the product distribution franchise $^{1}$ and the business-format franchise. It is the latter model of business-format franchises that is under discussion here. Most commonly, companies that opt to expand their business through franchising do so because it is an ideal mechanism for spreading expansionary risks while extending coverage (Australian \& New Zealand business franchise guide 2008, 4). The typical franchising process begins with a systematic conversion into intellectual property of the knowledge that an aspiring master franchisor has accumulated over the course of its establishment as a successful business. Once, as Stephenson puts it, condensed into franchise manuals the information is regarded as yet another asset of the company but, importantly, one that can be sold repeatedly with minimal risk of diminution or depreciation to franchisees. Through a contracted franchise system of monthly royalties, advertising fees and standard operating procedures, master franchisors are able to dictate both the terms by which franchisees operate and the manner in which profits are returned. As the name implies, then, at their most fundamental business-format franchises consist of a template for enterprise from which franchisees expect to start and run a successful business. To aspiring franchisees, franchising is commonly touted as an ideal way to start a business because all the hard work of setting up and running a business has already been completed by the master franchisor. In other words, franchising advocates a style of entrepreneurship that is akin to business-by-numbers.

The information contained within franchise manuals forms the basic building blocks of franchises. The contents of these manuals are standardized, for a couple of interrelated reasons. In the first place, they are meant to assure any franchisee that as long as they follow the step-by-step instructions, starting and running a business is a simple affair. At the same time, compliance with these instructions ensures that every product/service created and sold through a franchise is relatively the same. This, in turn, assures customers of a franchise that they can expect their needs to be met in a very specific manner. For instance, a customer walking into a McDonald's ${ }^{\mathrm{w}}$ outlet in Kuala Lumpur would expect the Cheeseburger available there to be the same as those served, say, in Reykjavik. This basic component of franchises is known as 'trademark value' (Birkeland 2002, 14) and one of the main reasons why franchises appeal to aspiring entrepreneurs who want to avoid the hurdle of attracting customers to an unknown product. In marketing terms, it is often restyled as brand recognition.

In his melding of franchises with nations, Stephenson picks up on and subtly remoulds the two main characteristics of franchises. The first of these is the fact that the most basic component of franchises resides in the information encapsulated in franchise manuals. The second is that master franchisors very quickly expand their businesses by recruiting other people's resources to serve their own commercial ends. Stephenson likens the data contained within franchise manuals to DNA and combines that with the self-replicating, predatory nature of the franchising process to suggest that franchises are viral in their manner of dispersion and growth. By placing franchise and nation side by side, Stephenson exposes and emphasizes the cold commercial rationale and aggressive instrumentalism underlying nations and national belonging and brings the pathological nature of nationalism to the fore. In the voice of one of its fictional purveyors, $\mathrm{Mr}$ Lee, Stephenson defines the franchise nation as 'a private, wholly extraterrestrial, sovereign, quasi-national entity' complete with its own 1800 number (Stephenson 1993, 92). Within this universe, or more rightly metaverse, the nation is a wholly commercial entity and national belonging yet another commodity to be acquired and traded at will to facilitate one's business objectives. 
Although franchise nation seems an unorthodox juxtaposition far removed from the realities of hard-won, place-based forms of identity and belonging, Stephenson's fictional device of franchise nations does actually have its equal in contemporary experience. In Flexible Citizenship (1999), for example, Ong discusses in detail the pragmatic brand of transnationalism and/or cosmopolitanism practised by families who aim to expand their familial and commercial connections on a global basis. Their pursuit of multiple, portable nationalities is motivated by an understanding of citizenship as a right to abode and, more importantly, to conduct business and gain employment within a nation. This understanding takes on meanings and forms in practices that persistently gainsay and transcend the traditional boundaries of the nation-state. In the years leading to Britain's imminent return of Hong Kong in 1997 to China's administration, for example, many of its citizens had cause to resort to exploiting overseas family and business connections to source alternative sites of residence, employment and investments for themselves. Though much of this was prompted by conditions beyond their control, such practices are a prime example of a consumerist attitude that regards nations as franchise outlets to be entered and patronized for one's advantage. However, it is not, as some might think, a luxury afforded only by the mobile affluent. Many others less affluent and less mobile aspire to the same, though they approach it differently. Two such examples are the 'Young Dragons' from China (Leong 2008) and the non-resident Indians (NRIs), ${ }^{2}$ who settle in countries like Singapore, Malaysia and Australia en route to bigger and brighter horizons. ${ }^{3}$ Together, the above examples suggest franchise nation to be a novum with pertinence for contemporary nations that far exceeds the boundaries of science fiction.

Stephenson's dramatization of national expansion and belonging as ruthless commerce based on the rapid replication of a formula has an unlikely scholarly counterpart in Benedict Anderson's Imagined Communities (1991), specifically Anderson's claim that the process of nation-state building owes something to the development of 'blueprints' (81). ${ }^{4}$ According to Anderson, the development of what - following Seton-Watson - he terms 'official nationalism' (86) began after the 1820s during European transitions from empires towards nationhood. ${ }^{5}$ It was, in his opinion, precisely because European models of nationalism, like that forged through the French Revolution, were shaped and fixed in print that they became 'known', 'generalizable' and available for 'pirating' and imitation $(80-1,155)$. Once crystallized in ink as 'the conceptual model' $(81-2)$, these European understandings of what the nation is 'imposed certain "standards" from which too-marked deviations were impermissible' (81). Anderson, however, never implies models of nations to be static in form. Rather, he insists that over time they have been adapted and transformed $(141,155-62)$. What he means is more readily understood if one considers the historical role that departing colonial powers like the British and French had in the embryonic, mid-twentieth-century formation of nations like Vietnam, Malaysia and Singapore. Although colonial input in the process of defining the first outlines of these nations is more obvious and direct in some instances than others, it is inevitable that these European architects should have drawn on models of the nation already developed in their homelands. Indeed, many signs of their imprint still exist in the Constitutions and structures of these nations. However, although Malaysia and Singapore have since gone on to prosper in the fashion intended by their European architects, Vietnam has developed in directions that have veered far from its prescribed templates. What this illustrates is that while the outline of a nation might be approximately determined, its actualization, how it is imagined, lived and experienced can and does vary widely. Indeed, a state of tension exists always between the conceptual model that is the nation and the constructions that are put to the concept through the enactment of notions like 'common citizenships, popular 
sovereignty, national flags and anthems' (Anderson 1991, 81). Though most widely read, even by its critics, as an argument for the role print media play in nation formation (Balakrishnan 1995; Chatterjee 1996; Mercer 1992; Postill 2006), Anderson's claim that many nations were initially constructed from formulaic models also lends solid theoretical credentials to Stephenson's portrayal of the nation as franchise.

So far, my discussion has centred on unpacking the concept of franchise nations. I want next to persuade that the concept offers insights into pragmatic views of the nation that are more prevalent and deeply rooted than commonly accepted. Towards this end, I consider next one of the most successful and prominent of franchise nations to date, namely China. I begin the examination of the China franchise by briefly tracing China's chequered relationship with its émigrés through the centuries. In doing so, my intention is to uncover the mesh of cultural, political and commercial forces that have historically impelled the outward spread and compelling reach of the China franchise. In what follows, I use two terms to denote Chinese emigrants. The first, 'overseas Chinese', is a broader term employed to describe those who live outside of mainland China but consider themselves of Chinese descent. This encompasses those who live in Taiwan, Hong Kong and Macau, as well as the Chinese populations who have made their homes in countries like Australia, the United States, Canada, Italy, the United Kingdom, Singapore, Malaysia, Japan, Thailand, Myanmar, Cambodia and the Philippines - the list is not exhaustive. Additionally, the term 'overseas Chinese' includes not just those who are first-generation emigrants but their many-generational families and offspring as well. The second term is xin yimin (new migrants), a collective term that describes specifically those who began to stream out of China some time in the 1960s (Kuhn 2008) or 1990s (Nyíri 2002). The two are, however, not mutually exclusive terms as xin yimin merely serves to differentiate from earlier emigrants the most recent group of Chinese to leave China.

\section{The China franchise}

The Chinese have a long-held tradition, that is, according to Kuhn $(2008,2)$ at least five centuries old, of exporting labour and remitting money home as a means of supplementing family income. Travel for the sake of employment and familial expansion are, therefore, themes well established in Chinese society. However, during the Song and Yuan dynasties, emigration was widely condemned as disloyalty to ancestors and ancestral land (Kuhn 2008, 960-1368) and, indeed, a severely penalized offence (Nyíri 2002, 208-9). Prevailing attitudes, therefore, meant that the practice of labour export was always couched as the enabling of sojourns rather than permanent migration. Instead of separation, then, the men, and it was usually the secondary males of households who left, were considered to be broadening the reach and connections of their families and home communities (Kuhn 2008, 4). This understanding applied to internal as well as external sojourns. Traditionally, Chinese emigrants were treated with suspicion and up until 24 October 1754, when Emperor Qianlong changed the emigration policy, all sojourners were subject to a three-year return deadline (Kuhn 2008, 91-4). Few sojourners, therefore, left with the stated intention to settle elsewhere permanently, though many did for various reasons.

For many of the sojourners, it was their shared dialect and hometown that comprised their main affinity groups (Kuhn 2008, 29). The sense of compatriotism they shared not only served as corridors of migration wherein recruitment, travel assistance and insurance were provided but it also remained the main source of sponsorship and patronage for sojourners once they arrived in their new, host societies (Kuhn 2008, 347; Pan 1999, 46, 61). 
As was the custom in China, it was the ties of compatriotism that provided for and determined the employment, accommodation, medical care and spiritual needs of the sojourners. For example, while the Hokkien of Fujian were considered most adept at large-scale trade, the Cantonese of Guangdong were recognized as skilled artisans, and the Hakka most successful at mining (Kuhn 2008, 172; Pan 1999, 47). ${ }^{6}$ Hence, occupations were mostly organized along dialect communal lines. Both within and outside of China, compatriotism had first call on communal affinity and preceded supra-dialect affinities like that of a pan-Chinese or national identity. Nonetheless, rather than opposing, compatriotism and nationalism were considered nested affinities (Kuhn 2008, 171).

General hostility towards emigration continued until some time in the $1860 \mathrm{~s}-1870 \mathrm{~s}$ when official attitudes, prompted by a number of events and developments, began to change. Among these events, the humbling the Chinese suffered at the hands of the British during the two Opium Wars of 1839-1842 and 1856-1858, sometimes known as the Anglo-Chinese Wars (Cotterell 1988, 224, 228), was pivotal to their change of heart. Another set of events was the appropriation of substantial tracts of Chinese territory by the Russians, Japanese, British and French that followed China's ignominious defeat (234). Upon realizing that the growing economic power and influence of the overseas Chinese could be wielded to arrest its declining power and influence, the imperial government began wooing the overseas Chinese in earnest (Kuhn 2008, 240-1; Zhuang 1999, 101). In 1893, for example, the Qing government repealed the ban on emigration (Kuhn 2008, 241; Pan 1999, 49). Additionally, in contrast to the earlier condemnation of departures as acts of disloyalty and filial impiety (Zhuang 1999, 98), the Chinese state set out to lay claim to its erstwhile sons and daughters. This culminated in 1909 with the passing of legislation that declared all children of Chinese fathers, regardless of where they were born, to automatically be citizens of China (Kuhn 2008, 243; Turnbull 1989, 196-7). ${ }^{7}$ These efforts were further intensified after the abdication of China's last emperor, Puyi, and the fall of the Qing dynasty in 1912 (Spence 1981, 118). The ensuing civil strife between the nationalists (Kuomintang) and the communists saw the various parties involved turn even more to the overseas Chinese for financial succour and political support (Kuhn 2008, 243-5). From the 1860s onwards, then, China sought to reclaim the loyalties of its overseas citizens. It was not until 1955 that China's policy of dual citizenship was renounced by Chou Enlai (Kuhn 2008, 330).

Beginning in the 1960s (Kuhn 2008) or 1990s (Nyíri 2002), depending on the point of reference, Chinese migrants of a different ilk began to stream out of China. It is this group that is largely known as xin yimin (new migrants). In contrast to the overseas Chinese of earlier eras, these new migrants appear less dependent on compatriotism, regional and dialect ties (Kuhn 2008, 350). Perhaps because of the spread of Mandarin in Chinese education and urbanization, they rely more on individual friendships and kinship (Kuhn 2008, 362). For example, study outside China has become a significant migration channel (356). In many instances, this has led students from mainland China, like those in the Netherlands (Li 2002), to organize themselves in cross-dialect patterns in order to pool their resources of connections, information and solutions for dealing with the pressures and realities of living in a foreign environment. It has also given rise in Singapore to the phenomenon of peidu mama (solo study mamas) who accompany their school-age children while they pursue their primary and secondary schooling overseas (Parliamentary Debates 2005). Rather than sojourners who reluctantly turn settlers, the overseas Chinese are now willing, even eager, emigrants.

At the same time, the global spread and sheer volume of Chinese venturing outside China for study, employment, business and leisure have led increasingly to a more 
pragmatic approach from the government based in Beijing towards the flow of Chinese overseas (Kuhn 2008, 364). Rather than a threat, the Chinese state now regards the overseas Chinese as necessary and advantageous to China's economic development and national security. As Nyíri (2002) suggests, the Chinese who have wandered far from their homeland have come full circle, from being branded class enemies to patriots. I contend this change in policy to be commensurate with the brand of pragmatic and instrumental politics that seeks to leverage economic, social and cultural capital for international advantage, an attitude encapsulated in the concept of franchise nation. Such change is evidenced in the warmth of the reception for emigrants and their families, with multiple agencies like the National Association of Overseas Chinese, Returned Overseas Chinese, and Dependents of Overseas Chinese and the Overseas Chinese Commission (shortened to Qiaoweihui) set up to protect the interests of the overseas Chinese (Kuhn 2008, 365; Nyíri 2002,212 ). Further proof of this change in policy is also apparent in the passing of measures to protect the interests of returned overseas Chinese and their dependants into law, together with the special quota for admission into institutions of higher education (Nyíri 2002, 212). Given the historical hostility towards emigrants, the establishment of these agencies by the state confers approval, recognition and legitimacy on them but, more importantly, it implants and reinforces the notion of their overseas presence as a branch or franchisee of the China franchise.

Franchising the nation as such also makes perfect fiscal logic as the sums involved in the many and frequent remittances and numbers of visits and investments of the overseas Chinese is an avenue of substantial national income. Though less structured and more emotively motivated, these incoming funds are not unlike the royalties that franchisees remit to franchisors on a regular basis. Evidence of the compulsion that xin yimin experience can be seen in Figure 1, taken by this author whilst on a shopping trip to one of Singapore's oldest malls. It shows the crowd milling outside the premises of a remittance agent, waiting patiently to send money back to China in time for the 2009 Lunar New Year (Spring Festival) celebrations. That this takes place despite the 'global financial crisis' and

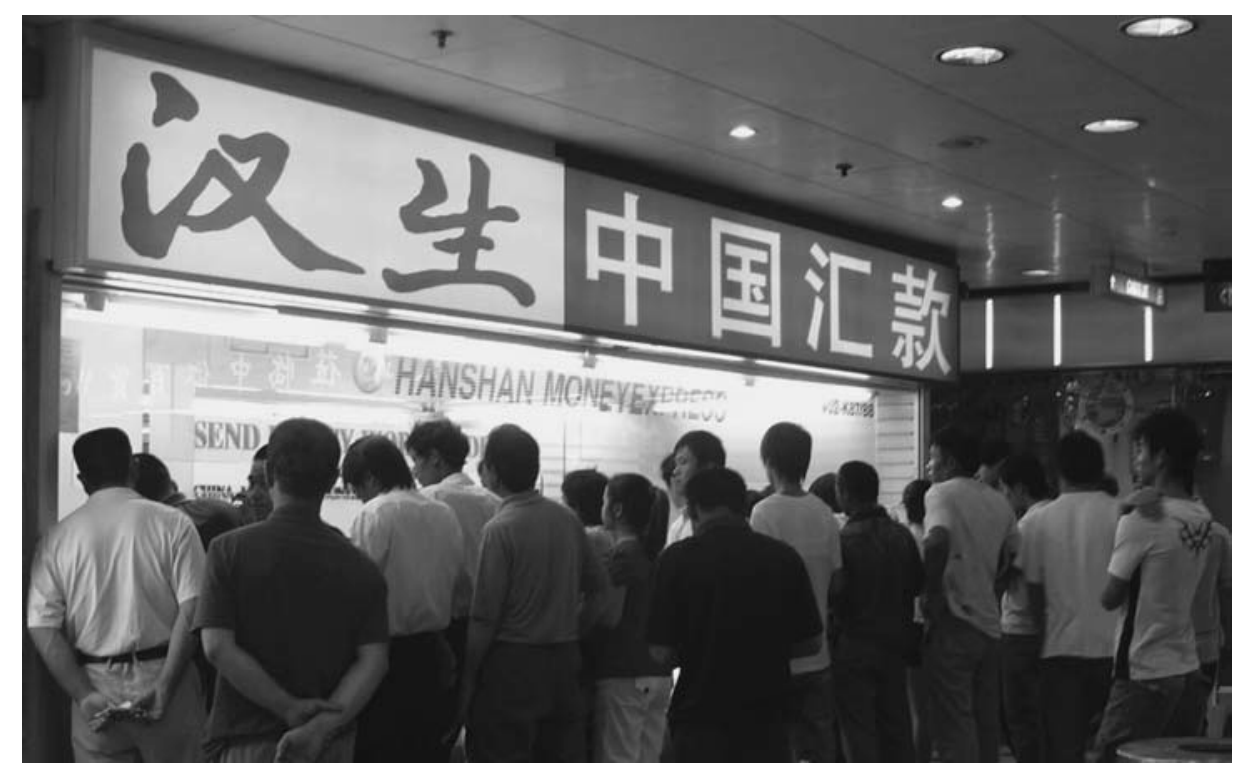

Figure 1. Remittance agent at People's Park Complex, Singapore. Photograph by author. 
the corresponding shrinkage of capital and opportunity at home and abroad is proof, indeed, that for many the deep emotional ties and obligations they hold in relation to China are of a kind not easy to shirk or ignore.

Today, as Brady $(2008,163)$ argues, '[g]aining influence over Overseas Chinese groups outside China' in order to make useful 'propaganda bases for China' of them remains a key objective of the Chinese Communist Party (CCP) propaganda machinery. By imbuing overseas Chinese with the love of nation, the state-run Central Propaganda Department (CPD) extends the reach of China and turns these satellite Chinese communities into part of the China franchise. Towards this end, the CPD has, since 1989 and more obviously in recent years, made concerted efforts to woo the Chinese both at home and overseas (Brady 2006, 74). The satellite television channel CCTV-4, for example, was established in 1992 specifically for the overseas Chinese audience (Brady 2008, 167). In 2000, CCTV-9 was set up to introduce China to English-speaking audiences both in and outside China (Brady 2008, 167). Notably, while CCTV-9 is allowed to be more liberal, CCTV-4 has a more 'overt political line' (167). The reach of the CPD extends all the way to the online world, and state-controlled print newspapers like China Daily enjoy an entrenched and impressive digital presence (http://www.chinadaily.com.cn), reaching figures of 3.2 million hits in a day (Brady 2008, 168). With its centralized operation and nth degree of control over the powers of persuasion, the CPD is remarkably similar to the head office-centric marketing structure that master franchisors impose on franchisees.

Indeed, since 2004, a similar kind of reach has extended to the export of Chinese language and culture through the establishment of Confucius Institutes at universities located across the world (University of Sydney 2008). The number of these institutes is set to grow from 314 in 81 countries to 500 worldwide by 2010 ( $\mathrm{Sim} 2009$ ). The bulk of them are currently situated in Europe and widely interpreted as China's attempt to exert 'soft power' (Bell 2009, 26; Maslen 2007). And the numbers are impressive, in 2008 alone, for example, the Confucius Institutes had 130,000 students passing through their gates ("Confucius Institute becomes "brand" for disseminating Chinese culture' 2009). I contend these institutes to be akin to franchise outlets in their roles as shop front, information source and training centre. Employing a centralized, co-ordinated structure, these Confucius Institutes promote, detail and instruct others, whether or not they are Chinese, on how to speak, read, write and appreciate all matters Chinese in a uniform, sanctioned and prescribed fashion. That these institutes are also sited with an eye to the overseas Chinese market is most obvious in Singapore where no fewer than two Confucius Institutes have been established. Although the island-state has a tiny, resident population of 4 million (Sim 2009), 75.2\% identify as ethnic Chinese (Saw 2007, 29). The presence of two Confucius Institutes in Singapore indicates that the Chinese state is well aware of the franchising potential that the majority Chinese population presents.

However, just as would-be business owners also seek out prospective franchises for investment, efforts to (re)connect with China are not unidirectional. Nor are they entirely engineered by the CPD or other PRC (People's Republic of China) authorities (Nyíri 2002, 219). Many overseas Chinese organizations and associations - formal and informal voluntarily 'seek guidance' (219) on the conduct of their activities. Much of this reciprocity has been egged on by mainland Chinese local government cadres eager to capitalize on the largesse and business connections of return emigrants. Very often, it is these return migrants' attempts at reconnection that see them sponsoring the construction of homes, schools and buildings in their home towns, participating in heritage activities and flaunting their financial success through the conduct of elaborate (and expensive) ceremonies to honour ancestors (Kuhn 2008, 372-4). As many mainland Chinese have 
quickly realized, there is much economic benefit to be gained from the 'roots business' (Ang 2003, 146).

Interest in China, though, has never been solely the purview of the overseas Chinese, as non-Chinese have long been intent on gaining entry to China as a market and a resource. The reopening of China since the 1970s has reinvigorated the interest of Western and nonWestern corporations outside of China. Their many attempts and failures to break into and establish successful ventures in communist China have led many to write about the cultural differences that make the Chinese market almost impenetrable. Examples include the two volumes Thick Face, Black Heart (Chu 1995) and The Asian Mind Game (Chu 2000). Returning emigrants, overseas Chinese entrepreneurs and foreign governments with overseas Chinese populations keen to leverage whatever cultural advantages they may possess over competitors have contributed to this trend, expounding upon the importance of concepts like 'face' and connections or networks (guanxi) to Chinese ways of doing business (Haley, Tan, and Haley 1998, 15, 123). Generally, their efforts reinscribe cultural stereotypes and have the effect of reinforcing cultural essentialism. However, correctly understood, this reversion is a form of 'ethno-essentialism' wherein an 'alien people produce an essentialist notion of themselves' (Carrier 1992, 198), in these instances in order to profit from purported connections.

The efforts of the government and majority Chinese population of Singapore are again a good example. Its elder statesman Lee Kuan Yew is famed for espousing Confucianderived Asian values as a point of differentiation (Barr 2000). In more recent times, he has been effusive in his support of China ('MM Lee hails China's reforms' 2008) and continues unabashedly to urge Chinese-speaking Singaporeans to capitalize on their connections and language skills for business in and with China ('MM Lee says Singapore's bilingual education policy reaping dividends in China' 2008). That this message has been well received and integrated by the nation's members is reflected by the fact that Singapore is China's seventh largest investor (International Export Overseas, Ministry of Trade and Industry, Singapore 2009). On a very different level, it is also evident in this letter published in Singapore's English daily The Straits Times, wherein the Singaporean Chinese writer, speaking on his experience of working in China, urges fellow citizens to take advantage of whatever 'little language advantage we have' before it vanishes with the voracious uptake of English by the Chinese (Tan 2009).

Responses such as those in Singapore are typical of many nations with significant populations of Chinese descent, sometimes referred to by the term 'Greater China' ${ }^{8}$ What these management gurus, government leaders and the occasional economist perpetuate is the myth that 'Chineseness' can be encapsulated in unassailable cultural traits and passed down biologically, even to those who have never experienced life in China. Further, that these characteristics can be brought forth at will and deployed to establish and expand the commercial ventures of overseas Chinese in China. The formula for success they advocate is based on the assumption that cultural codes contained and condensed into race or ethnicity can somehow bias one towards business success in the nation of racial/ethnic origin. The history of the changing fortunes of Confucianism as a philosophy central to China and Chinese ways provides proof aplenty of the error of their assumptions about race or ethnicity as essential, unchanging categories. That these categories are emphatically not so has been most soundly argued through the work of Hannaford (1996), Said (1978) and Reynolds (2008). Nonetheless, the prevalence of such assumptions lends credence to my argument that the concept of franchise nations is a relevant and useful approach for thinking about the contemporary developments of the nation. To offer a preliminary idea of how this might work, in the next section I examine some of the controversies that plagued the China franchise in 2008. 
Specifically, the protests and counter-protests surrounding the Tibetan struggle for sovereignty mounted during the Olympic Torch Relay in Paris, London and Canberra; and the Sichuan earthquake in May.

\section{The China franchise in (new) media}

It is important to understand the importance of the Beijing Olympics for the China franchise (Brownell 2008). Having lost the bid to host the prestigious sporting event in 2000 , the 2008 Olympics was China's long-sought chance to take centre stage and reclaim its status as a global economic and political powerhouse. The entire exercise from the construction of specially commissioned sports venues and the Torch Relay to the opening ceremony was regarded and organized as a huge publicity event, intended to showcase China to its own populace and the rest of world. The many pro-Tibetan and anti-China protests organized during the Beijing Olympics Torch Relay relied on this understanding of the Chinese state's objectives. As such, they were deliberate attempts to both ride on and disrupt the Chinese government's attempts to grow the China franchise. However, as subsequent events proved, the pro-Tibet protests also roused the nationalism latent in many overseas Chinese, who rallied to support a beleaguered China. An analysis of the actions and interactions of the various parties involved is instructive because it offers an insight into how a franchise nation gathers momentum and mobilizes its franchisees.

Tibetans-in-exile and their allies have always lamented China's rule of Tibet, so the dispute between China and Tibet is not new. However, in 2008, pro-Tibet protests flared around the world, sparked off initially by anti-China unrest in Lhasa on 14 March 2008, and spread to other parts of the world when the Olympic Torch Relay began in London on 6 April ('Tibet unrest spreads beyond Lhasa' 2008; 'Monks disrupt Tibet media visit' 2008; 'Weeping monks disrupt Lhasa media tour' 2008). A raft of pro-China rallies was quickly organized in response (Bennhold and Rosenthal 2008; Curiel and Lagos 2008; Spencer, Edwards, and Thomas 2008). Like the pro-Tibet rallies, the pro-China ones were designed to take place alongside the Torch Relay and rolled across the globe in tandem with the relay's itinerary ('Pro-China rally in Australia' 2008; 'Tight security for Australia Olympic relay' 2008; 'Crazy Chinese mobs and Olympic Torch Relay in Seoul' 2008; 'Olympic torch causes violence in Seoul' 2008). Coverage of these pro-China events was captured, adroitly broadcast and touted as a demonstration of Chinese patriotism by the state-run CCTV-4 channel to the wider overseas Chinese audiences (see 'CCTV4 news about the 4.13 demonstration in Sydney' 2008). At various points, video footage was also posted online by both pro- and anti-China protestors to spread the news and engage as well as mobilize others to their cause (see 'Tibet was, is, and always will be a part of China' 2008; 'Unfair media, London 4.6 Olympic Torch Relay, different voic' 2008; ‘中国加油! !9]ANTI-RIOT \& EXPLORE THE TRUTH in Vancouver 3/29’ 2008).

Protests and counter-protests continued to rage until 12 May when Sichuan, China, was shaken to its core by a powerful earthquake resulting in 70,000 fatalities, an estimated 374,000 injured and 5 million homeless ('Magnitude 7.9 - Eastern Sichuan China' 2008). The reactions of the world media were expectedly sympathetic and rendered more so by the plight of many children trapped, hurt and fatally injured by the collapse of poorly constructed schools. However, it was the online responses of the overseas Chinese and the manner in which they were couched that are most illuminating. For example, although many appeals for aid were phrased in much broader, humanitarian terms by some (Federation of Chinese Scholars in Australia 2008; Chua 2008), not all were thus. In one Chinese version posted on the World Wide Web established specifically by residents of 
Boston, Massachusetts, terms like tongbao (fellow countrymen or citizen) and huaren (Chinese race) were used continuously and quite matter-of-factly to convey a sense of fraternity and shared kinship (“波士顿华人支援四川地震灾区 ${ }^{10}$ 2008). Appeals such as the latter are proof par excellence of the China franchise at work as their framing draws deeply on the sense of a pan-Chinese identity, patriotism and nationalism. Similar tropes were at work on 19 May, a week after the earthquake, when a three-minute silence was observed nationwide at 2.28 p.m., the exact time the disaster occurred ('Standing united in silence' 2008). Media footage of the millions of people, vehicles and vessels standing stock still at various sites was widely broadcasted and subsequently spliced together with a rousing call to collective national mourning and bracing as part of the Chinese race (zhungguo mingzhu) for an overseas Chinese audience on CCTV-4 (TongTech 2008). However, what was perhaps most stirring took place in Tiananmen Square after the three-minute silence, where seemingly spontaneous waves of patriotism overwhelmed the mourners who started shouting pro-China slogans (Joshuazh 2008).

Foreign media, which had previously been highly critical of China's efforts to subdue foreign media coverage of the Olympics, now switched their focus to the China's government's management of both the disaster and its media portrayal. Many of these foreign observers praised the CCP government for its media transparency on the scale of the disaster and the outstanding earthquake relief efforts (wimmeke75 2008a, 2008b;

'World reacts to China quake' 2008). Again, the state was quick to compile and beam these international endorsements back to English-speaking audiences in and outside China on CCTV-9 ('CCTV-9: UN Security Council mourns earthquake victims' 2008). I argue these all to be evidentiary of the Chinese state's understanding of nation as franchise and demonstration of its success at 'marketing propaganda' (Brady 2008).

The Beijing Olympics was declared opened on 8 August. In an opening ceremony directed with trademark flair by prodigal son Zhang Yimou (Bingham 2008), millions of well-drilled and uniformly black-haired and black-eyed Chinese men, women and children set out to impress the world with the lore of the Chinese civilization. The antiquity, magnificence and homogeneity of the 5000-year-old China franchise was put on grand display and the Chinese invention of four major technologies: paper, movable type, compass and gunpowder duly valorized and lauded. The China franchise's triumphant return to the world stage as a player was proudly declared to a worldwide audience. No one knows for sure how many overseas Chinese hearts swelled with vicarious pride at the sight and memory of such poetry, innovation and cohesion but estimates put the total global audience at the four billion mark. The dividends, or more accurately, royalties, are bound to come in time.

While it is possible to dismiss much of the above, from the Olympics Torch Relay counter-protests and the many appeals to fellow countrymen for disaster relief to the mass mourning as the reaction of the first-generation overseas Chinese, composed largely of scholars sent overseas (many on government grants) or, alternatively, as the actions of hired mobs, I suggest that such a reading is too simplistic and overly cynical. The willingness of overseas Chinese to defer to and mobilize themselves in public demonstrations outside China is not new and the PRC has taken advantage of this in the past to convey outrage over Taiwan's secessionist plans (Nyíri 2002, 235). Further, as these videos demonstrate, overseas Chinese going back generations as well as those of Chinese descent born overseas derive great pride from signs of the rise of China, including Beijing's staging of the 2008 Olympics. ('Overseas Chinese, why are they pro-China?' 2008; Eberlein 2008; “万人五四集会:：纽约华人支持奥运'11 2008). Indeed, many were acutely indignant that a more equitable media representation of affairs in China and Chinese society was not forthcoming. What all of the above implies is that Chinese 
nationalism and national belonging are not the sole domains of first-generation overseas Chinese but rather genuinely experienced with great depth of feeling by the overseas Chinese across generations. It seems the China franchise runs deep, wide and far. What the above also seems to suggest is that the responses of the overseas Chinese take on a particularly virulent form in new media. I suspect this is due, in some part, to the sense of unfiltered immediacy and (putatively) global accessibility associated with new media, which encourages rapid, impulsive and emotive online expressions. Unchecked, these passionate pleas and fiery flourishes can reach and impinge on audiences that are distant but by no means uninvested in how the Chinese are perceived by others. For negative media coverage and demonization of China and all things Chinese can provoke fierce sentiments in and towards members of a visibly different but highly competitive ethnicity, whatever their location.

There are some, like Shen $(2007,198)$, who argue that this turn towards new media is unique to China because of the relative freedoms cyberspace offers over a domestic population used to a repressed public sphere and media. At the same time, according to him, the Chinese do so with little expectation that their demands will be acted on by the Chinese party-state. I suggest such an account flawed, for amongst other things it ignores the simple fact that new media responses can just as easily be pro-CCP as they are against. Additionally, the explanation loses sight of the efforts of the CCP to build on the affective ties of the overseas Chinese and enhance the legitimacy of a pan-Chinese future. I propose instead that the violence of feeling and political activism the Chinese (both overseas and at home) gave vent to during the course of 2008 is better and more fully understood if regarded as manifestations of the success of the China franchise. For what is at stake in these contestations of portrayal is more than the political, economic or cultural. To approach thinking about these developments of the Chinese nation purely as a political or economic or cultural phenomenon alone is the route to a limited and impoverished understanding. Rather than view the events related above as ominous signs of the rise of China, then, I contend them to be better understood as indications of the broader trend towards franchise nations, one consistent with and contextualized within the increasing flow of people, capital and goods across borders.

\section{Conclusion}

As the pace of global travel intensifies and family migrations in search of better conditions and futures become commonplace, the size of diasporas is set to expand across the world. We need a way to think about and understand these communities that takes the myriad economic, political and cultural motivations at play into consideration, for the absence of so many from their home nations (and their presence elsewhere) cannot fail to influence how the nation is understood, imagined and lived. Others have problematized the notion of 'long-distance nationalism' (Anderson 1994, 326). I submit that of equal urgency is an entry point into the multi-faceted process by which diasporas are created, courted, mobilized and engaged by their home nations and the consequences this holds for the future of the nation. The concept of franchise nations responds to the challenges of these new, often volatile complexities in a manner that is original and appropriate to the moment. For the franchise nation model recasts the emerging issues within the contexts of tensions between home and host nations and, in relationship to the material conditions of globalization, neoliberalism and multiple migrations. In doing so, franchise nation moves the discussion of nations and their diasporas on from the notion of imagined communities and allows their rapid growth and expansion to be analysed against a much richer and more nuanced background. 
The emphasis in this paper has been on the China franchise. However, the concept of franchise nations is by no means applicable to China alone. As Nyíri (2002, 230) notes, many nations actively encourage their diasporas to maintain their levels of socio-political involvement in their home nations. Though China is, at this point in history, unique in the enormity (and visibility) of the overseas Chinese population, India faces similar prospects. Between 1995 and 2025, India's English-educated and multitudinous population is poised to grow to 401 million (Heilig 1996). If current projections are accepted, the strength and size of the Indian diaspora, otherwise known as the NRI population, will soon outstrip that of the China franchise. Concurrently, while Indian cinema in the guise of Bollywood is fast gaining a global audience, vocal diaspora born and bred in foreign lands like the United Kingdom have developed distinctive expressions of their sense of 'Indianness'. From comedies like Goodness, Gracious Me (1998) and sitcoms like The Kumars at No. 42 (2001) to movies like Bend it Like Beckham (2002), the franchise that is India is gradually being added to and nurtured through the production and distribution of diasporic media. What the intersections of these developments mean for the highly visible Indian franchise is yet to be determined but there are already signs that their combined effects will be substantial (Kamdar 2007). In 2003, the Indian government amended its Citizenship Act to retroactively admit members of the Indian diaspora resident in specific countries as 'overseas citizens' (Citizenship (Amendment) Bill 2003). However, such developments are not confined to the newer, less-established nations. France, for example, has only recently proposed that the Gallic diaspora resident in 11 locations - Britain, Switzerland, Germany, the Iberian peninsula and Monaco, eastern Europe, the Asia-Pacific region, Latin America, the United States, the Middle East and two in Africa - be represented as foreign constituencies, complete with their own elected Members of Parliament ('France to create MP seats to represent expatriates' 2009). Even less populous nations like Singapore set up an Overseas Singapore Unit in 2006 with the expressed aim to plan and co-ordinate multi-agency programmes and initiatives' to engage overseas Singaporeans (National Population Secretariat 2008). ${ }^{12}$ It has since then opened the Overseas Singaporean web portal, which at the last count listed 28 overseas Singaporean communities within the Australia-Pacific alone. Among other activities, the portal organized a Singapore Day in Perth, Australia, in 2008 and another in London in 2009 (Overseas Singaporean Portal 2006). In the latter instance, use was made of Singaporean cuisine, 'home-grown' media talent, visions of home now, career opportunities and ringtone downloads as draw cards. The potpourri of delights is clearly designed to hold on to those somewhat precariously positioned (geographically as well as metaphorically) outside the nation. As a young nation of less than 50 years' vintage formed largely through immigration, Singapore can make no claim to the heritage of an ancient civilization. Nonetheless, its government has set out deliberately to engage its diasporic community through the manufacturing of essential traits out of the well-known Singaporean penchant for good food, employment prospects and technology. The demands of such extended links are two-way. Diasporic communities, for example, have not been backward in using their overseas presence to plea the cause(s) of their home nations. The recent diplomatic efforts of the US government on behalf of the Tamil minority caught up in the middle of the Sri Lankan government's war with Tamil separatists is one example of the fruits of active lobbying by one's diaspora (“"Engage Tamils” to end conflict' 2009).

All of the above incidences, methods and strategies as well as the responses such actions elicit and cultivate are typical of how franchises operate. As such, these are exactly the kinds of contemporary developments that can benefit from scrutiny with the franchise nation approach. Importantly, what these contrasting examples of India, France, Singapore 
and Sri Lanka point to is this: that when it comes to the franchising of nations, the size of the diasporic population is secondary to the home state's intentions to establish some form of influence over its diaspora, and the responses - vociferous, tepid or otherwise - their overtures provoke from these communities. Neither, as the examples cited also suggest, are such interactions confined to any one region, or kind of nation. In fact, the nationdiaspora scenarios described above are increasingly the norm rather than the exception. How nation-states deal with and respond to the issues that the movements of their mobile citizenries present, and how diasporas themselves maintain, abandon, juggle, extend and enact the entangled ties of belonging to multiple nations are, therefore, matters that require immediate attention and analysis. The concept of franchise nations offers a fresh and innovative way to approach and open up this important discussion.

\section{Acknowledgements}

I am indebted to the Faculty of Media, Culture \& Creative Arts, Curtin University of Technology for funding me to attend and present this paper at the CSAA 2008 conference. I also wish to thank Michele Willson, Kristen Philips, Denise Woods and both anonymous reviewers for their feedback, comments and assistance in the development of this paper.

\section{Notes}

1. There is another type of franchising, known as a product distribution franchise, which is used by manufacturers primarily to distribute bulky, expensive and/or complex machinery to areas where access is either difficult or too costly (Birkeland 2002, 2).

2. Non-resident Indians (NRIs) is a term commonly used to denote Indian nationals who live outside of India for purposes of business, employment and study, etc. In many ways it is the Indian equivalent of overseas Chinese.

3. China, in common with many other countries like India, Singapore and Malaysia, does not allow dual citizenship. However, multiple allegiances in the form of permanent residence in other nations is possible, and indeed much valued, by those seeking opportunity outside China.

4. The question of who maps out the blueprint is, of course, an important one though not a query that can be discussed with any justice here. For more detail, see Chatterjee (1996).

5. Anderson describes it rather vividly as the process whereby 'the short, tight, skin of the nation' was stretched 'over the gigantic body of the empire' (1991, 91). Examples include the attempts of imperialists like Macaulay to turn the people of the Indian sub-continent into people who were English in everything except skin colour.

6. There is no consensus on the number of Chinese dialects that exist in China but, according to at least one source, there are nine main Chinese dialect groups as well as many non-Chinese speaking ones (Chao 1976). The fact that many of these dialects are mutually non-intelligible to non-speakers adds to the exclusionary effect of dialect group belonging.

7. For many of the sojourners-turned-migrants who had settled as minorities in Southeast Asia, this declaration by Beijing made the overseas Chinese the subject of doubt on the question of their loyalties and caused their host societies much anxiety. Many overseas Chinese in Thailand, for example, were treated badly but failed to win protection from a China depleted in economic power and military strength (Kuhn 2008, 270-1).

8. The term 'Greater China' has its roots in the Chinese practice of regarding the regions of the empire 'directly controlled by the central administrative bureaucracy' as 'China Proper' and those regions outside of central administration but under the suzerainty of the Chinese as 'Outer China'. During the Qing dynasty, 'Outer China' included Manchuria, Mongolia, Chinese Turkestan and Tibet (Harding 1993, 661-2). It is a term now used in everyday parlance to denote a number of different concepts but the three main concepts that Greater China incorporates, according to Harding (661) are: 'economic integration, cultural interaction and political reunification'. The term is flexible in its scope but commonly includes Taiwan, Hong Kong, Macau and Singapore.

9. 'Go China Go!'

10. 'Boston Chinese aid Sichuan earthquake'.

11. 'May 4: Chinese New Yorkers gather to support the Beijing Olympics'.

12. I am grateful to Terence Lee for sharing this information with me. 


\section{Notes on contributor}

Susan Leong is Adjunct Postdoctoral Fellow at Curtin University of Technology, Faculty of Media, Culture \& Creative Arts. Her research interests include the nation; the implications of new media for Asian and Australian imaginaries; ethnic minorities and pluralism in Malaysia and Singapore; the notion of the lived; and the inclusion/exclusion of internet non-users. She is currently extending the concept of franchise nations, with specific reference to the Chinese and Indian diasporas.

\section{References}

Anderson, B. 1991. Imagined communities: Reflections on the origin and spread of nationalism. London: Verso. 1994. Exodus. Critical Inquiry 20: 314-27.

Ang, I. 2003. Together-in-difference: Beyond diaspora, into hybridity. Asian Studies Review 27, no. 2: $141-54$.

Australian \& New Zealand business franchise guide. 2008. 2nd ed. Mt Eliza, Vic.: CGB.

Balakrishnan, G. 1995. The national imagination. New Left Review 211, May/June: 56-69.

Barr, M.D. 2000. Lee Kuan Yew and the 'Asian values' debate. Asian Studies Review 24, no. 3: 309-34.

Bell, D.A. 2009. War, peace, and China's soft power: A Confucian approach. Diogenes 56, no. 6: 26-40.

Bend it Like Beckham. Written and Directed by G. Chadha. United Kingdom: Kintop Pictures, 2002.

Bennhold, K., and E. Rosenthal. 2008. Olympic torch goes out, briefly, in Paris. http://www.nytimes. com/2008/04/08/world/europe/08torch.html (accessed 29 November 2008).

Bingham, J. 2008. Beijing Olympics: Zhang Yimou - the director behind the opening ceremony. http://www.telegraph.co.uk/sport/othersports/olympics/2524791/Beijing-Olympics-ZhangYimou-the-director-behind-the-opening-ceremony.html (accessed 2 December 2008).

Birkeland, P. 2002. Franchising dreams: The lure of entrepreneurship in America. Chicago: University of Chicago Press.

Blanchot, M. 1959/2006. The proper use of science fiction. Trans. R. Savage. In Imagining the future: Utopia and dystopia, ed. A. Milner, M. Ryan, and R. Savage, 375-383. Melbourne: Arena Publications Association.

Brady, A.-M. 2006. Guiding hand: The role of the CCP Central Propaganda Department in the current era. Westminster Papers in Communication and Culture 3, no. 1: 58-76.

- 2008. Marketing dictatorship: Propaganda and thought work in contemporary China. Lanham, MD: Rowman \& Littlefield.

Brownell, S. 2008. Beijing's Games: What the Olympics mean to China. Lanham, MD: Rowman \& Littlefield.

Carrier, J.G. 1992. Occidentialism: The world turned upside-down. American Ethnologist 19, no. 2: $195-212$.

CCTV4 news about the 4.13 demonstration in Sydney. 2008. http://au.youtube.com/watch?

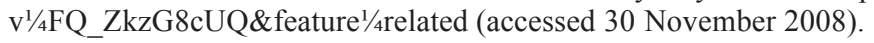

CCTV-9: UNN Security Council mourns earthquake victims. 2008. http://www.youtube.com/watch? $\mathrm{V}^{1 / 4}$ _lorfzqdr4c (accessed 2 December 2008).

Chao, Y.R. 1976. Aspects of Chinese sociolinguistics: Essays. Stanford: Stanford University Press.

Chatterjee, P. 1996. Whose imagined community? In Mapping the nation, ed. G. Balakrishnan, 214-25. London: Verso.

Chu, C-N. 1995. Thick face, black heart: Thriving and succeeding in everyday life and work using the ancient wisdom of the East. St Leonards, NSW: Allen \& Unwin.

. 2000. The Asian mind game: Unlocking the hidden agenda of the Asian business culture. St Ives, NSW: Stealth Productions.

Chua, K.S. 2008. Urgent assistance required for earthquake victims in Sichuan, China. http://www. huaren.org (accessed 20 November 2008).

Citizenship (Amendment) Bill. 2003. Republic of India. 2003. www.rajyasabha.nic.in/bills-ls-rs/ 2003/XXXIX_2003.pdf(accessed 12 May 2009).

Confucius Institute becomes 'brand' for disseminating Chinese culture. 2009. http://paper.people. com.cn/rmrb/html/2009-03/13/content_210625.htm (accessed 23 July 2009).

Cotterell, Arthur. 1988. China: A concise cultural history. London: John Murray.

Crazy Chinese mobs and Olympic Torch Relay in Seoul. 2008. http://www.youtube.com/watch?

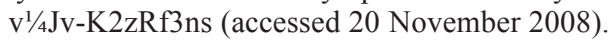

Curiel, J., and M. Lagos. 2008. Pro-Tibet protesters climb Golden Gate Bridge cables. http://www.sfgate. com/cgi-bin/article.cgi?f1/4/c/a/2008/04/07/MN6L101A0U.DTL (accessed 29 November 2008). 
Eberlein, X. 2008. Are overseas Chinese more patriotic? http://www.insideoutchina.com/2008/05/ are-overseas-chinese-more-patriotic.html (accessed 20 November 2008).

'Engage Tamils' to end conflict. 2009. http://www.straitstimes.com/Breaking\%2BNews/Asia/Story/ STIStory_361315.html (accessed 9 April 2009).

Federation of Chinese Scholars in Australia. 2008. Appeal for donation: China 'Sichuan Earthquake Surviving Children's Education Fund'. http://www.focsa.org.au/FOCSA_event_earthquake_ sichuan.html (accessed 30 November 2008).

France to create MP seats to represent expatriates. 2009. The West Australian 18: 46, April.

Goodness, Gracious Me. 1998. Television program. London: BBC.

Haley, G.T., C.T. Tan, and U.C.V. Haley. 1998. New Asian emperors: The overseas Chinese, their strategies and competitive advantages. Oxford and Boston: Butterworth Heinemann.

Hannaford, I. 1996. Race: The history of an idea in the West. Washington, DC: Woodrow Wilson Center Press.

Harding, H. 1993. The concept of 'Greater China': Themes, variations and reservations. China Quarterly 136: 660-686, December.

Heilig, G.K. 1996. Chapter 1. World population: Major trends. http://www.iiasa.ac.at/Research/ LUC/Papers/gkh1/chap1.htm (accessed 2 December 2008).

International Export Overseas, Ministry of Trade and Industry, Singapore. 2009. China market information., http://www.iesingapore.gov.sg/wps/portal/MI_NorthAsia_China (accessed 7 April 2009).

Joshuazh. 2008. 天安门广场万人齐呼中国加油声音响彻青罙 [Tiananmen Square reverberates to the thunder of thousands gathered shouting Go China Go!; my translation]. http://www. youtube.com/watch? $\mathrm{v}^{1 / 4} / \mathrm{tiaZmT7WuOQ}$ (accessed 12 December 2008).

Kamdar, M. 2007. Planet India: How the fastest-growing democracy is transforming America and the world. New York: Scribner.

Kitchin, R., \& Kneale, J. 2002. Lost in space: Geographies of science fiction. London: Continuum.

Kuhn, P.A. 2008. Chinese among others: Emigration in modern times. Lanham, MD: Rowman \& Littlefield.

The Kumars at No. 42. 2001. Television program. London: BBC.

Leong, W.K. 2008. Young Dragons: Many are well-educated, speak competent English. http:// justwoman.asiaone.com/Just\%2BWoman/Story/A1Story20081124-102899.html (accessed 24 November 2008).

Li, M. 2002. A group in transition: Chinese students and scholars in the Netherlands. In Globalizing Chinese migration: Trends in Europe and Asia, ed. P. Nyíri and I.R. Saveliev, 173-88. Aldershot: Ashgate.

Magnitude 7.9 - Eastern Sichuan, China. http://earthquake.usgs.gov/eqcenter/recenteqsww/Quakes/ us2008ryan.php\#summary (accessed 20 November 2008).

Maslen, G. 2007. Australia: Warning - be wary of Confucius Institutes. http://www. universityworldnews.com/article.php?story¹/420071130094503100 (accessed 21 July 2009).

Mercer, C. 1992. Regular imaginings: The newspaper and the nation. In Celebrating the nation, ed. T. Bennett, 26-46. Sydney: Allen \& Unwin.

MM Lee hails China's reforms. 2008. http://www.asiaone.com/News/AsiaOne\%2BNews/ Singapore/Story/A1Story20080925-89998.html (accessed 2 November 2008).

MM Lee says Singapore's bilingual education policy reaping dividends in China. 2008. http://sg. news.yahoo.com/cna/20081119/tap-902-mm-lee-says-spores-bilingual-edu-231650b.html (accessed 26 November 2008).

Monks disrupt Tibet media visit. 2008. http://news.bbc.co.uk/2/hi/asia-pacific/7315895.stm (accessed 29 November 2008).

National Population Secretariat, Singapore Government. 2008. Overseas Singaporean Unit. http:// www.nps.gov.sg/osu.htm (accessed 11 March 2009).

Nyíri, P. 2002. From class enemies to patriots: Overseas Chinese and emigration policy and discourse in the People's Republic of China. In Globalizing Chinese migration: Trends in Europe and Asia, ed. P. Nyíri and I. Saveliev, 208-41. Aldershot: Ashgate.

Olympic torch causes violence in Seoul. 2008. http://www.youtube.com/watch?v1/4L4QTBDurA5U (accessed 29 November 2008).

Ong, A. 1999. Flexible citizenship: The cultural logics of transnationality. Durham, NC: Duke University Press. 
Overseas Chinese, why are they pro-China? 2008. http://www.youtube.com/watch? $\mathrm{v}^{1 / 4 G 3 G 33 K H G 2 B Q}$ (accessed 29 November 2008).

Overseas Singaporean Portal. 2006. Australia-Pacific. http://www.overseassingaporean.sg/cms/index. php/portal/overseas_singaporean_websites/osw_australia_pacific/ (accessed 11 March 2008).

Pan, L. 1999. The encyclopedia of the Chinese overseas. Cambridge, MA: Harvard University Press.

Parliamentary Debates: Official Report, Tenth Parliament. 2005. 80, no. 11: 1467-1468, Parliament of Singapore.

Postill, J. 2006. Media and nation building: How the Iban became Malaysian. New York: Berghahn.

Pro-China rally in Australia. 2008. http://news.bbc.co.uk/player/nol/newsid_7340000/ newsid 7345600/7345670.stm (accessed 29 November 2008).

Reynolds, $\bar{H}$. 2008. Nowhere people. Camberwell, Vic.: Penguin.

Said, E.W. 1978. Orientalism. New York: Pantheon.

Saw, S.H. 2007. The population of Singapore (2nd ed.). Singapore: Institute of Southeast Asian Studies.

Shen, S. 2007. Redefining nationalism in modern China: Sino-American relations and the emergence of Chinese public opinion in the 21st century. Basingstoke: Palgrave Macmillan.

Sim, C.Yi. 2009. China expands language network abroad. The Straits Times, 13 March. Factiva: http://global.factiva.com (accessed 16 March 2009).

Spence, J. 1981. The gate of heavenly peace. New York: Penguin.

Spencer, R., R. Edwards, and D. Thomas. 2008. 'Olympic torch extinguished amid Paris protests. http://www.telegraph.co.uk/news/uknews/1584225/Olympic-torch-extinguished-amid-Parisprotests.html (accessed 29 November 2008)

Standing united in silence. 2008. http://au.youtube.com/watch?v1/4M74YWxqkjdc (accessed 20 November 2008).

Stephenson, N. 1993. Snow crash. London: Roc.

Suvin, D. 1979. Metamorphoses of science fiction. New Haven: Yale University Press.

Tan, P. 2009. Why it's so crucial. http://news.asiaone.com/News/Education/Story/A1Story20090 406-133593.html (accessed 6 April 2009).

Tibet unrest spreads beyond Lhasa. 2008. http://news.bbc.co.uk/2/hi/asia-pacific/7299597.stm (accessed 29 November 2008).

Tibet was, is, and always will be a part of China. 2008. http://www.youtube.com/watch? $\mathrm{v}^{1 / 4} / 4$ QQNKB34cJo (accessed 7 October 2008).

Tight security for Australia Olympic relay. 2008. http://www.youtube.com/watch?v1/43cBcjnVejjo (accessed 10 December 2008).

TongTech. 2008. 3 minutes silence in China on May 19, 2008 14:28. http://au.youtube.com/watch? $\mathrm{V}^{1 / 4}$ chPUqiso (accessed 7 October 2008).

Turnbull, C.M. 1989. A history of Malaysia, Singapore and Brunei. Sydney: Allen \& Unwin.

Unfair media, London 4.6 Olympic Torch Relay, different voic. 2008. http://www.youtube.com/ watch? $1 \frac{1}{4} \mathrm{fNgT} 5 \mathrm{HdCqg} 4$ (accessed 13 May 2008).

University of Sydney. 2008. The Office of Chinese Language Council International (Hanban). http:// www.usyd.edu.au/confucius institute/about/hanban.shtml (accessed 27 November 2008). Weeping monks disrupt Lhasa media tour. 2008. http://www.abc.net.au/news/stories/2008/03/27/ 2200959.htm (accessed 29 November 2008).

wimmeke75. 2008a. China earthquake: China gives full press freedom. http://www.france24.com/ en/EN\%20DPX\%20CHINA\%208H0513 400.wmv (accessed 2 December 2008).

wimmeke75. 2008b. China earthquake: Foreign media comments. http://www.cctv.com/video/ NewsHour/2008/05/NewsHour_300_20080514_8.shtml (accessed 2 December 2008).

World reacts to China quake. 2008. http://www.youtube.com/watch? $\mathrm{v}^{1 / 4} \mathrm{CpswlgGq} 1 \mathrm{wA}$ (accessed 2 December 2008).

Zhuang, G. 1999. Relations with China. In The encyclopedia of the Chinese overseas, ed. L. Pan, 98-103. Cambridge, MA: Harvard University Press.

万人五四集会:纽约华人支持奥运 . 2008. http://www.sinovision.net/news.php?act $1 / 4$ details\& col_id $1 / 46 \&$ news_id $1 / 444892$ (accessed 29 November 2008).

中国加油 ANTI-RIOT \& EXPLORE THE TRUTH in Vancouver 3/29. 2008. http://www.youtube. com/watch? $v^{1 / 4 U N S j J T X s v 2 E ~(a c c e s s e d ~} 30$ November 2008).

波士顿华人支援四川地震灾区. 2008. http://www.bostonaidsichuan.org/ (accessed 29 November 2008). 